\title{
Pathology of the Nervous System in Von Hippel- Lindau Disease
}

\author{
Alexander O. Vortmeyer, Ahmed K. Alomari \\ Yale School of Medicine, Department of Pathology, Division of Neuropathology, Connecticut, USA.
}

\begin{abstract}
Von Hippel-Lindau (VHL) disease is a tumor syndrome that frequently involves the central nervous system (CNS). It is caused by germline mutation of the VHL gene. Subsequent VHL inactivation in selected cells is followed by numerous well-characterized molecular consequences, in particular, activation and stabilization of hypoxia-inducible factors HIF 1 and HIF2. The link between VHL gene inactivation and tumorigenesis remains poorly understood. Hemangioblastomas are the most common manifestation in the CNS; however, CNS invasion by VHL disease-associated endolymphatic sac tumors or metastatic renal cancer also occur, and their differentiation from primary hemangioblastoma may be challenging. Finally, in this review, we present recent morphologic insights on the developmental concept of VHL tumorigenesis which is best explained by pathologic persistence of temporary embryonic progenitor cells.

Received: 14 May 2015; Accepted after revision: 06 June 2015; Published: 11 June 2015

Author for correspondence: Alexander O. Vortmeyer MD, PhD, Yale School of Medicine, Department of Pathology, Division of Neuropathology, Connecticut, USA. E-mail: alexander.vortmeyer@yale.edu

How to cite: Vortmeyer AO, Alomari AK . Pathology of the Nervous System in Von Hippel-Lindau Disease. Journal of Kidney Cancer and VHL 2015;2(3):114-129. Doi: http://dx.doi.org/10.15586/jkcvhl.2015.35
\end{abstract}

\section{Introduction}

Von Hippel-Lindau (VHL) disease is an autosomal dominant disorder that is caused by germline mutations in the tumor suppressor gene VHL on chromosome 3p25 $(1,2)$. It is characterized by frequent development of selective tumor types in specific topographic locations. Among others, central nervous system (CNS) hemangioblastoma and clear cell renal cell carcinoma (RCC) are the most consistently encountered tumors (3).

Tumorigenesis in VHL syndrome is linked to the loss of VHL tumor suppressor protein function in cell differentiation (47).The loss of protein function is the result of a second genetic "hit" which inactivates the wild type VHL allele (8). Subsequent to VHL gene inactivation and loss of VHL protein function, hypoxia-inducible factors (HIF1 and HIF2) are activated (9-11). HIF1 is a heterodimer transcription factor composed of HIF $1 \mathrm{a}$ and HIF $1 \beta$ subunits (12). Through conditional transcriptional activation of effectors controlling vascularization, glucose metabolism and cell differentiation, HIF 1 plays an important role in cellular response to oxygen changes (12). HIF2a (also known as endothelial PAS domain-containing protein -1 (EPAS1)) is another hypoxia-inducible factor that functions as an integral component of transcription factors involved in the body response to low oxygen level 
(13). In comparison to HIF1a which is expressed ubiquitously, HIF2a has a restricted tissue distribution and is expressed primarily in the vasculature of early developing embryo and subsequently in the lung, kidney interstitial cells, liver parenchyma, and neural crest cells (14).

VHL protein is part of a multiprotein complex that targets $\mathrm{HIFa}$ subunits for ubiquitin-mediated degradation in proteasomes $(11,15-19)$. In hypoxic conditions or with VHL biallelic inactivation, both HIF1a and HIF2a subunits will evade degradation, accumulate in the cell and complex with other subunits to form functional proteins $(9,10,20)$. The consequences of HIF $1 \mathrm{a}$ and HIF2a up-regulation are multifaceted. One major change includes the transcriptional activation of genes containing hypoxia responsive elements. VEGF is among the target genes that will be overexpressed leading to enhanced angiogenesis and oxygen delivery (12, 21). Additionally, HIF2a up-regulation is linked to enhanced dysregulated erythropoiesis while HIF2a deletion has been shown to result in anemia associated with decreased expression of erythropoietin $(22,23)$.

Despite the significant alterations at the cellular and molecular levels in association with VHL silencing, it has remained unclear, however, why loss of VHL function and subsequent HIF activation lead to tumorigenesis. Molecular and structural analogies of tumor cells with developmental tissues $(6,14,24,25)$ have led to revisitation of the hypothesis of a developmental origin of VHL diseaseassociated tumors $(26,27)$. There is increasing evidence that the "second hit" causes loss of pivotal VHL function during organ development leading to maldeveloped structures that represent prerequisites for tumor formation (28).

In VHL disease, the CNS is predominantly affected by hemangioblastic tumorigenesis, but may also be involved by endolymphatic sac tumors (ELST) or metastatic disease.

\section{Hemangioblastomas}

Hemangioblastomas of the nervous system are present in $80 \%$ of VHL patients and represent a defining feature of VHL syndrome $(3,29)$. Topographic distribution of these tumors show a consistent pattern with the retina, cerebellum, brainstem and dorsal spinal cord being the most frequently involved locations (3). With recent advancements in sensitive imaging techniques, there has been a shift in the distribution of these tumors with increasing proportion of spinal tumors in comparison to the pre MRI era (30). Supratentorial tumors represent less than $3 \%$ of all tumors in most series $(30,31)$. In contrast to sporadic hemangioblastomas, VHL patients frequently have multiple hemangioblastomas, as is the case in 127 out of 160 patients in one report (30).

\section{Clinical and radiological presentation}

Hemangioblastomas are benign tumors with no metastatic potential. However, as with other space occupying lesions of the brain, they may cause neurological deficit and carry a significant mortality rate if left untreated due to hydrocephalus, tonsillar herniation and brainstem compression (29, 32). Not infrequently, these tumors have an associated pseudocyst or syrinx evident by magnetic resonance imaging (MRI) (33) (Figure 1). In addition to this cystic component, which may be much larger than the tumor itself, these tumors have a typical MRI appearance of densely contrast-enhancing solid mass with smooth margins $(30,34,35)$.

\section{Pathological features}

The gross appearance of these tumors commonly shows a solid nodule with an associated pseudocyst. Pseudocysts result from secretory tumoral activity (33) and disappear after successful surgical removal of the tumoral nodule (33). The tumoral nodule is usually soft with bright or dark red color, and occasional yellow areas seen upon sectioning (28). Histological findings vary greatly and are dependent on tumor size (25). There are two main cellular constituents of hemangioblastomas, "stromal" cells and vascular cells. By selective genetic analysis, "stromal" cells have been shown to be neoplastic cells $(36$, 37). The origin of the "stromal" cell has been controversial (38); however, most consistently proposed has been a 

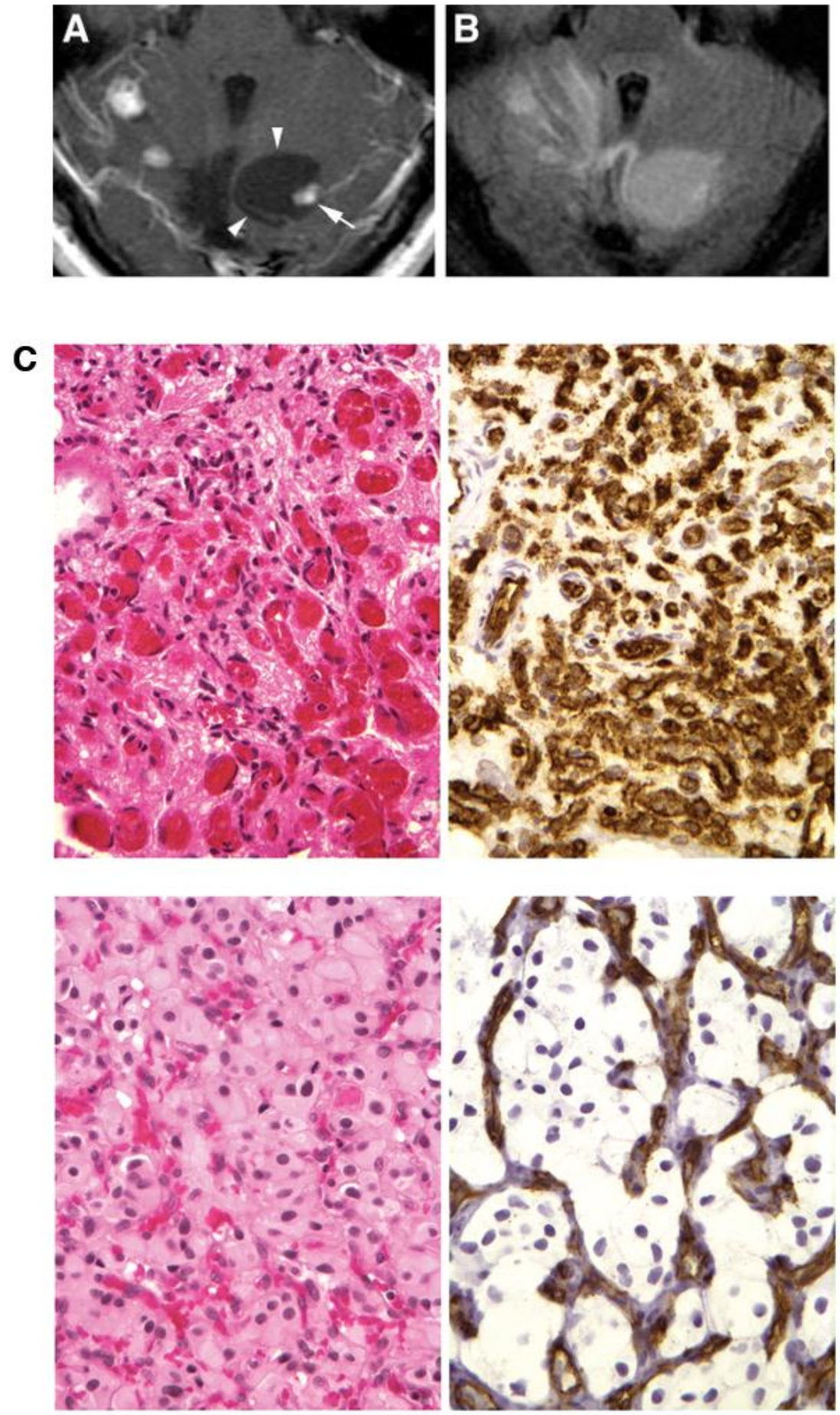

Figure 1. Radiological and histologic presentation of hemangioblastomas. A, T1-weighted postcontrast MR image shows right cerebellar hemangioblastoma (arrow) with an associated cyst (arrowheads); B, corresponding precontrast, fluid-attenuated inversion recovery, MR image demonstrating cyst hyperintensity (from Lonser et al., Ann Neurol 2005;58:392-399). C, Hemangioblastoma may present with mesenchymal (upper) and epitheloid structures (lower); Immunohistochemistry for vascular antigen CD34 reveals reactive vascularization (upper and lower right), neoplastic cells are negative for anti-CD34 (from Shively et al., J Pathol 2008;216:514-20). 
hemangioblastic or hemangioblastic progenitor origin $(27,39-42)$. Since hemangioblasts were originally discovered in embryonal tissues almost 100 years ago (43-45) and are not known to exist in adult CNS tissue, the concept of a developmental origin of hemangioblastoma developed early $(26,27)$ and will be further discussed below.

The second cellular constituent of hemangioblastoma is represented by abundant vascular cells that show no evidence of biallelic VHL inactivation and are therefore mostly - if not entirely reactive $(36,46)$. The most plausible explanation for the abundance of reactive vascular structures in hemangioblastoma is the tumoral "stromal" cell expression of angiogenic factors (47). However, whether a subset of vascular structures may represent differentiation products of neoplastic hemangioblastic "stromal" cells (vasculogenesis) has been investigated with controversial results.

Most immunohistochemical studies identify "stromal" cells and vascular cells as separate cytological constituents with no evidence of transition between the two cell types: they either report distinct immunoreactivity with different markers of interest (48-52) or find vascular markers factor VIII and/or factor XIIIa exclusively expressed in the vascular component of tumors $(48,53)$. In contrast, other studies reported expression of vascular markers in "stromal" cells (54-56). Cell culture studies either revealed no evidence of interconvertibility between endothelial cells and "stromal" cells (57) or evidence for vascular differentiation capacity of "stromal cells"(58). Microdissection studies revealed evidence for vasculogenesis in precursor structures of hemangioblastomas (59), but not in frank tumors (46).

Within hemangioblastomas, the proportion of "stromal" and vascular cells can vary greatly and has been used as the basis of the traditional morphologic subclassification of hemangioblastoma into a vascular-rich reticular (also called "mesenchymal") cell phenotype and a "stromal" cell-rich cellular (also called "epitheloid") variant (60) (Figure 1). A study of 156 variably-sized hemangioblastomas revealed strong correlation between histologic subtype and tumor size (25). In the aforementioned study, all tumors smaller than $8 \mathrm{~mm}^{3}$ showed exclusive reticular structure, also known as "angiomatotic", or "mesenchymal", that is characterized by small loosely scattered tumor cells separated by extensive vascularization (25). Larger tumors reveal additional phenotypic change, neoplastic stromal cells that are enlarged in size with abundant cytoplasm and large nuclei, and frequently clustered in groups (25). Cytologically, the stromal cells in these latter neoplasms may have an abundant glycogen or lipid-rich cytoplasm imparting a clear appearance of the cell on routine $\mathrm{H} \& \mathrm{E}$ sections. Foci of extramedullary erythropoiesis can be detected in cellular (epitheloid) areas, but are not detected in reticular (mesenchymal) tumor portions. It has therefore been postulated that reticular lesions represent an earlier stage of tumorigenesis from which epitheloid tumor with extramedullary erythropoiesis may develop (25). Interestingly, these morphologic changes within individual hemangioblastomas have previously been interpreted as different stages of embryonic hemangioblastic maturation (40).

\section{Endolymphatic Sac Tumors}

The endolymphatic duct/sac system is composed of single-lumen thin long endolymphatic duct ending in a short pouch-like endolymphatic sac (61). The interior of this system is lined by singlelayered cuboidal endolymphatic duct/sac epithelium (62). The intraossesous part of the endolymphatic duct/sac system is also referred to as the vestibular aqueduct (63) and represents the site of origin of ELST (64). The endolymphatic duct/sac system is part of the nonsensory membranous labyrinth of the inner ear with a potential functional role in maintenance of homeostasis and pressure of the inner ear, phagocytosis of debris and immunologic functions $(65-68)$.

\section{Epidemiology}

ELST was first established as a distinct pathologic entity by Heffner in 1989 (69). However, ELST had not been recognized as 

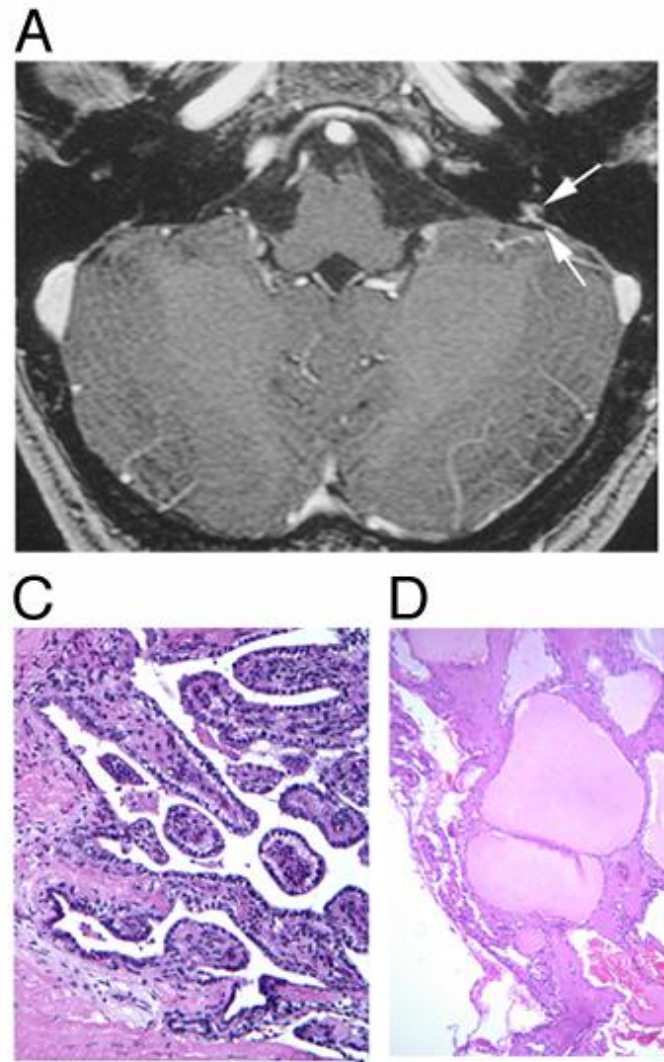

D
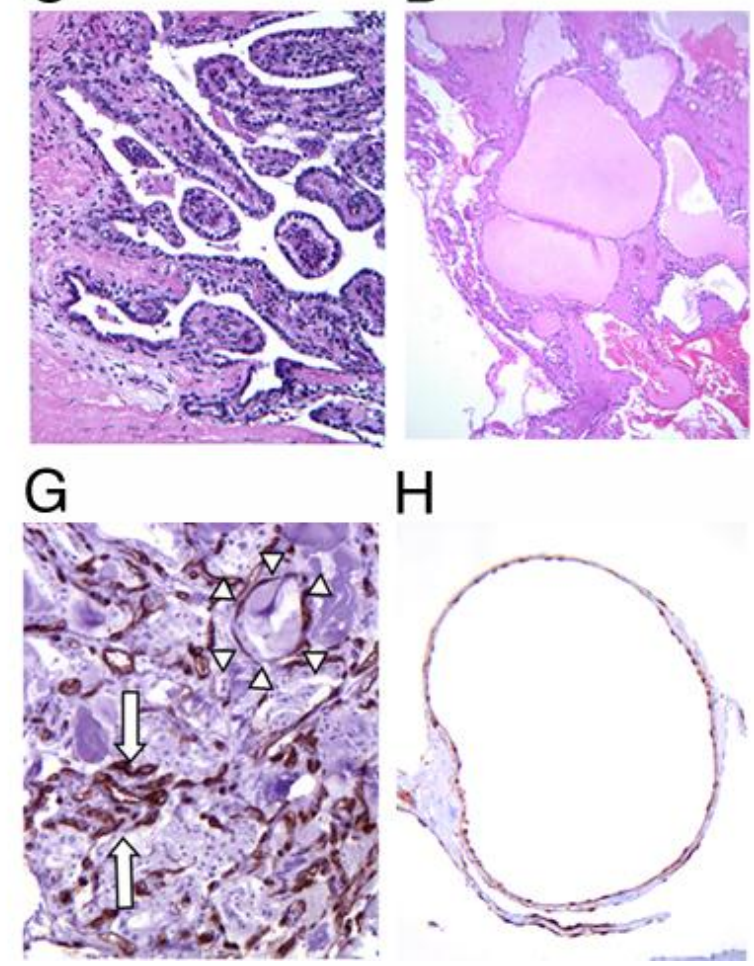

$\mathrm{H}$

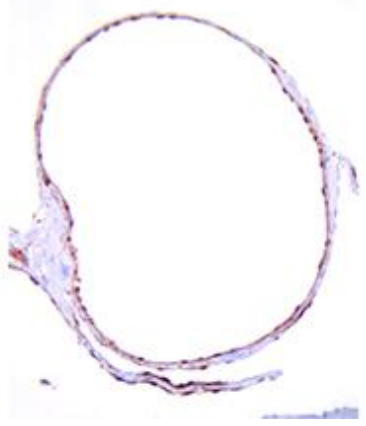

B

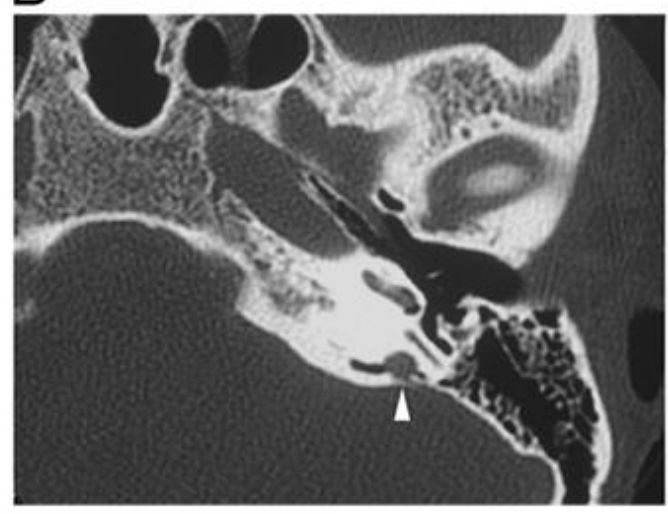

$\mathrm{F}$
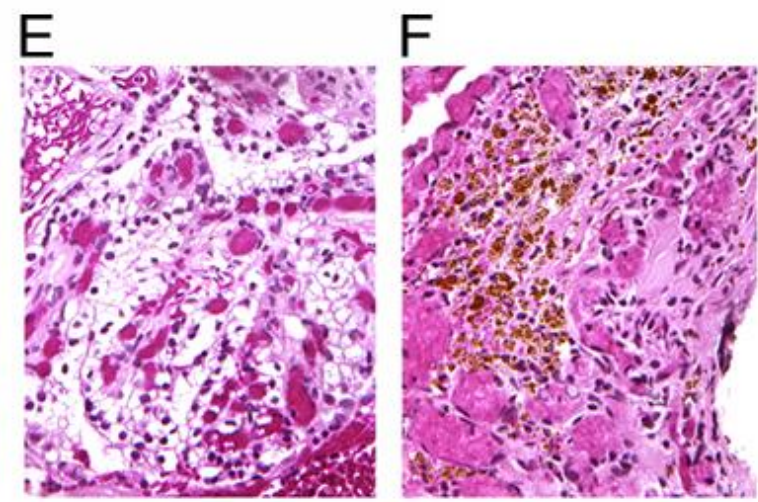

I

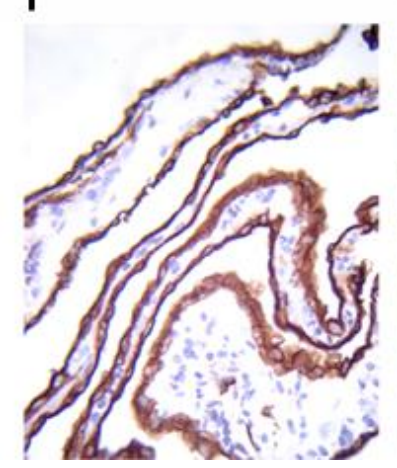

$J$

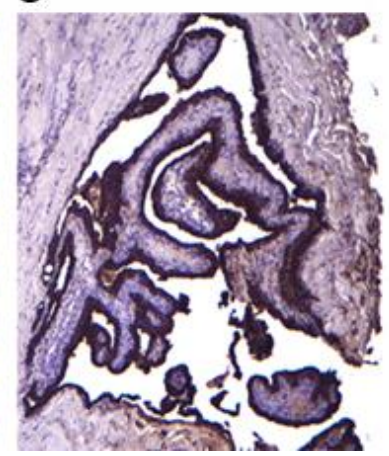

Figure 2. Radiologic, morphologic and immunohistochemical features of ELSTs. Serial magnetic resonance (MR) and computed tomography $(\mathrm{CT})$-imaging of the temporal region from a VHL patient with hearing loss demonstrating the development of a left endolymphatic sac tumor. (A) Axial, T1weighted enhanced MR-imaging reveals enhancement in the region of the left endolymphatic duct (arrows). (B) Corresponding, axial, non-enhanced, CT of the left temporal bone shows bony erosion confined to the left endolymphatic duct (arrowhead). Morphologic spectrum of ELSTs: Papillary structures were observed in all tumors (C), whereas cystic areas (D) were seen in half of the cases. One tumor had areas of epitheloid clear cell clusters (E), reminiscent of clear cell renal carcinoma. Extensive hemosiderin deposits were evident in half of the tumors (F). A feature of all tumors was intensive vascularization (G, immunohistochemistry with anti-CD 34). Note the abundant vessels in papillary stroma (arrows) and the immediate contact of numerous small vessels with the cystic epithelium (arrowheads), which appears to be induced by expression of HIF and VEGF by the epithelial tumor cells. Immunohistochemistry for NSE (H), MAK6 (I) and AE1/AE3 (J) was consistently positive (from Glasker et al., Cancer Res 2005;65:10847-53). 
a component tumor of VHL disease until 1997, after the identification of 15 inner ear tumors in 13 out of 121 patients with VHL disease, while none of 253 patients without evidence of VHL disease had inner ear tumors (70). Additional studies documenting VHL inactivation by microdissection and PCR-based loss of heterozygosity analysis provided genetic and molecular confirmation of this association $(64,71,72)$. Moreover, neoplastic cells were found to show activation of both HIF1and HIF2 as well as expression of CAIX and GLUT-1 which are downstream targets of HIF, and coexpression of EPO and EPOR, which has been implicated in promotion of tumor growth $(64,73)$. The prevalence of ELST in VHL patients has been reported to be approximately $10 \%$ to $15 \%$ based on imaging studies, with $30 \%$ of these patients having bilateral tumors (74).

\section{Clinical presentation}

ELST can cause hearing loss, tinnitus, vertigo and facial nerve paresis (75). Hearing loss can occur in larger tumors with invasion of the otic capsule, but also in smaller tumors. The proposed mechanisms of hearing loss in these tumors include hemorrhage and/or endolymphatic hydrops $(76,77)$.

\section{Morphology}

ELSTs present grossly as bright or dark red soft tissue masses (76). The histological appearances of these tumors are variable and are usually composed of a mixture of three main architectural patterns; papillary, cystic and epithelioid clear cell $(64,69)$. One consistently observed feature is the presence of extensively vascularized papillary structures. These papillary structures are lined by a single row of cuboidal epithelial cells. Focal cystic growth can be observed in a subset of tumors as is focal clusters of epitheloid clear cell. The cysts have a single epithelial lining and frequently contain proteinaceous material. Mitotic figures are rare. Extensive hemosiderin deposits are common and associated with degenerative features including fibrosis, inflammation and cholesterol cleft formation (Figure 2). Immunohistochemical analysis of VHL disease-associated ELSTs reveals positive immunoreactivity with anti-NSE, antiMAK6, and anti-AE1/AE3 (64, 78). Immunohistochemistry for EMA and S100 is positive in subsets of cases (79). Some sporadic tumors have also been reported to be positive for GFAP and vimentin (78).

In addition to frank tumors, multifocal microscopic cystic and papillary structures were identified in the intra- and extraosseous endolymphatic duct/sac system in VHL patients (64). These structure were different in their molecular profile from similar cystic proliferations identified in non VHL patients; in VHL patients, the cystic and papillary structures showed loss of the wild-type VHL allele in addition to positive nuclear staining for HIF1 and HIF2 and expression of target proteins CAIX and GLUT-1 $(64,80)$. It has been proposed that these structures represent tumor precursors (64).

\section{Metastasis}

Metastasis into the nervous system can occur from three different types of VHL disease-associated tumors. Most frequently, metastasis is caused by RCC which often may show striking resemblance to primary hemangioblastoma or ELST. Far less frequently observed are metastatic pheochromocytoma / paraganglioma or metastatic neuroendocrine tumors.

\section{Metastatic renal clear cell carcinoma}

Metastasis of RCC can occur anywhere within the nervous system. However, if metastasis occurs into cerebellum, brainstem, or spinal cord, differentiation from primary hemangioblastoma may constitute a diagnostic challenge. Both tumors share histologic features including cells with clear or vacuolated cytoplasm, extensive vascularization and occasional clustering of epitheloid cells. Additionally, both tumors share VHL gene deficiency as well as expression of VEGF, HIF, CAIX and other VHL target proteins. Several subtle morphological features have been proposed to help differentiate these tumors. Most importantly, cytoplasmic membranes are more distinct in renal cell carcinoma, while less well defined in hemangioblastoma 


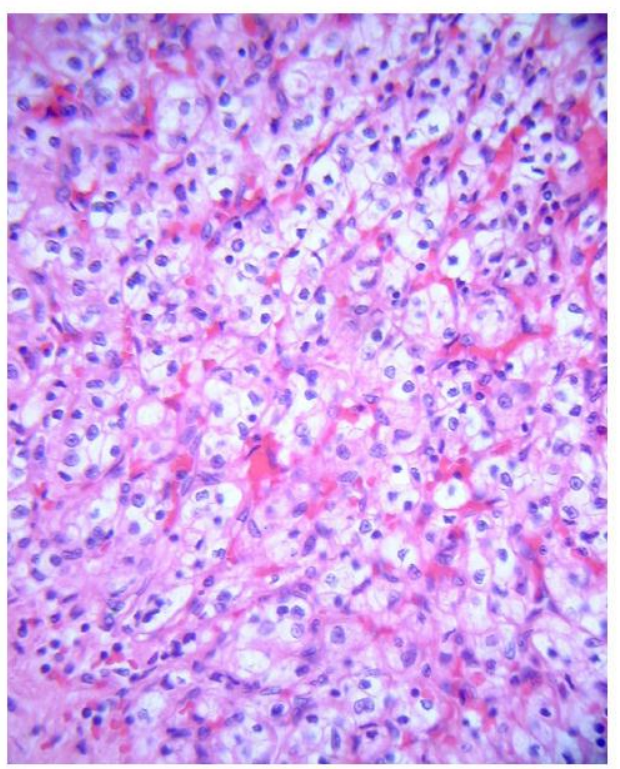

Figure 3. Metastatic RCC. Left, Metastatic renal cell carcinoma to brain resembling hemangioblastoma, $\mathrm{H} \& \mathrm{E}$ stain; right, immunohistochemistry for EMA shows characteristic membranous staining.

cells. Also, identification of mitotic figures strongly favors metastatic renal cell carcinoma. Necrosis is virtually never seen in hemangioblastoma, unless tumors had been pretreated with radiation or embolization (28).

Immunohistochemistry is a valuable tool to distinguish hemangioblastoma from metastatic RCC. Epithelial membrane antigen (EMA) was originally described to selectively identify $\operatorname{RCC}(81,82)$. However, focal expression of EMA may rarely occur in hemangioblastoma (83) (Figure 3). Antiinhibin A showed a high sensitivity and specificity for hemangioblastoma in one study (84). Other potentially useful markers include anti-CD10 for the identification of RCC and D2-40 and aquaporin-1 for the selective identification of hemangioblastoma (85-88). More recently, a combination of PAX-2 and PAX8 (positive in RCC) and inhibin A (positive in hemangioblastoma) has been proposed as the most useful panel of markers to resolve this differential diagnosis (89). Another important role of immunohistochemistry is the identification tumor heterogeneity that is caused by tumor metastasis into hemangioblastoma which is being reported in up to $8 \%$ of hemangioblastomas $(90,91)$.

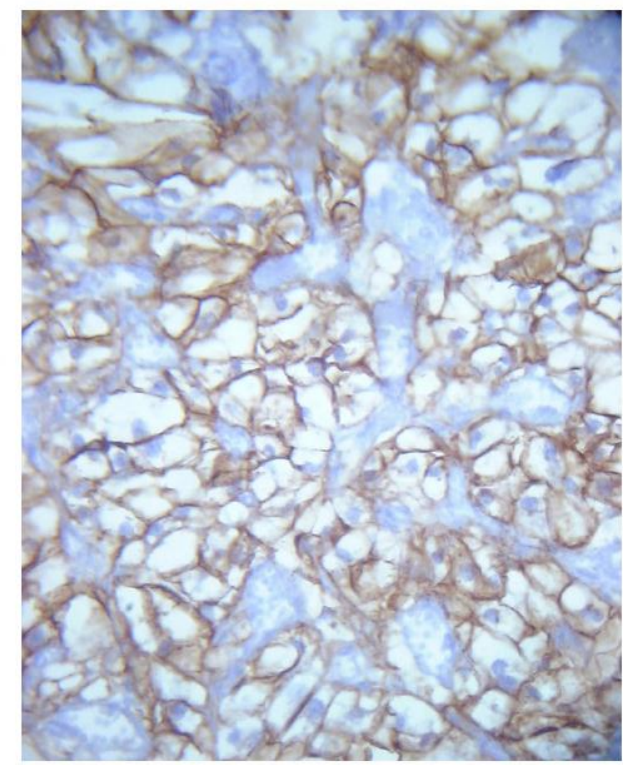

\section{VHL tumorigenesis}

Development of tumors in VHL diseaseArvid Lindau's hypothesis

Decades ago, the hypothesis of a hemangioblastic nature of CNS tumors in VHL disease fueled an even older debate on the origin of cancer which notably has not been settled until today. In the early and mid-1800s, Joseph Recamier and Robert Remak both noted that cancer tissue resembled embryonic tissue (92). In 18741875 Francesco Durante and Julius Cohnheim proposed cancer to originate from small collections of embryonal cells that persist and do not differentiate into mature adult tissue (92-94). In the early 1900 s, this theory was rejected $(92,95$, 96). When, however, Arvid Lindau discovered and described in detail the gross and histologic changes of VHL disease, he came to the conclusion that "...all types of neoplasia might be explained by a disturbed balance during mesodermal development during the third month of embryonal life" (26). While Arvid Lindau was therefore a strong supporter of the "embryonic rest"-hypothesis to explain CNS tumorigenesis in VHL disease, he subsequently noted that "an underlying early maldevelopment" may give rise to two 
A.

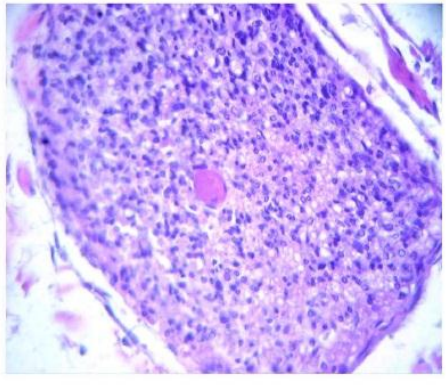

D.

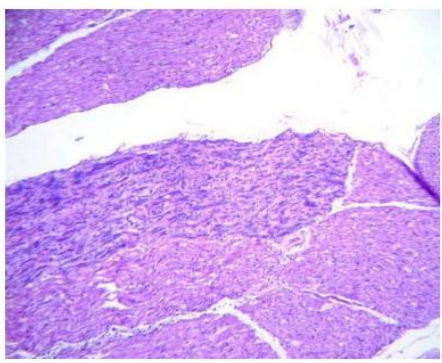

B.

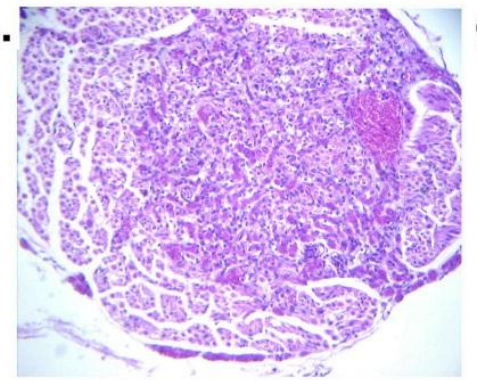

E.

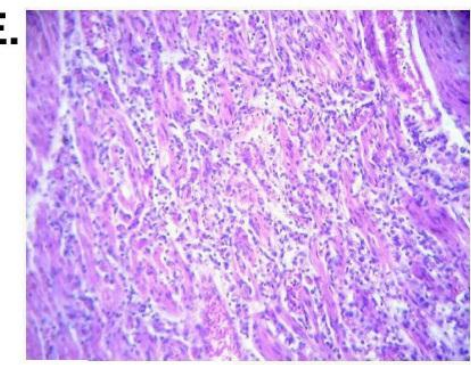

C.

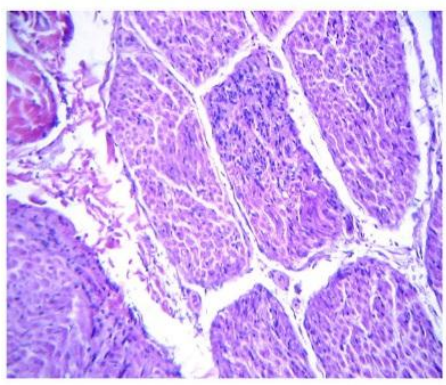

F.

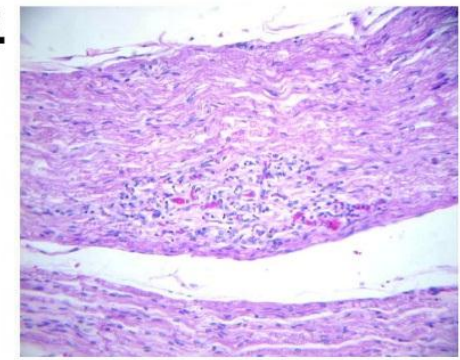

Figure 4. Developmentally arrested structural elements (DASEs), incidentally discovered in grossly normal-appearing nerve root tissue of VHL patients by histologic analysis of random spinal cord sections obtained at autopsy (from Vortmeyer et al., Ann. Neurol. 2004; 55:721-728). All depicted DASEs were present intradurally in different nerve roots. All lesions reveal circumscribed accumulations of persistent embryonal VHL-deficient hemangioblast progenitor cells (see references 24 and 98). A, cross-section of a nerve root, filled with embryonal cells; B, The central portion of the root shows an accumulation of embryonal cells which is sharply demarcated from surrounding normal root tissue; C, A longitudinal nerve root section reveals frequently observed longitudinal extension of DASE's along fiber tracts; D, intraradicular DASE with embryonal cells, diffusely scattered around neurites; E, DASE, selectively involving a central nerve root fascicle; F, circumscribed DASE in nerve root; focal clear cell phenotype and early multifocal vascular perfusion may indicate early progression into hemangioblastoma.

different pathologic processes "Hemangioblastoma" and "capillary angiomatosis" (27). He was, however, unable to explain how "early maldevelopment" can produce such extreme neoplastic diversity: a tumor composed of hemangioblastic cells on one hand, and a tumor composed of mature vascular cells on the other.

\section{Lindau's hypothesis - analytical and experimental evidence}

More recently, we worked on a resolution of this seemingly contradictory nature of VHL disease-associated CNS tumors. Key strategy for this effort was to change the primary target of histologic analysis. Instead of analyzing tumor tissues, we analyzed normal-appearing tissues of VHL patients in which tumors are known to frequently occur, spinal cord and cerebellum.

The study of tumor-free central and peripheral nervous system tissue of VHL patients revealed numerous microscopic structures that are not encountered in similar tissues of non-VHL control patients (24, 64, 97, 98) (Figure 4). In essence, these structures represent the "early embryonal maldevelopment" postulated by Lindau and have hence been designated "developmentally arrested structural elements" (DASEs) (97). DASEs represent precursors of CNS tumors in VHL disease; however, only a small number of DASEs progress to frank tumor during the lifetime of a VHL patient $(24,25,97)$.

The key constituent of DASEs are small primitive VHL-deficient cells that 
$\begin{array}{lrr}\text { apparently } & \text { represent } & \text { immature } \\ \text { hemangioblast } & \text { progenitor } & \text { cells, }\end{array}$ accompanied by reactive vasculature $(24$, 97, 98) (Figure 4). Early tumor arising from DASEs is highly vascularized and resembles "angiomatosis". Upon further tumor growth, tumor cells increase in size, develop epitheloid architecture and may differentiate in blood $(25,42,58)$. The morphologic sequence of tumorigenesis from DASEs to frank tumor reveals transition of mesenchymal cells into epitheloid structures and thus explains the diverse and complex histologic presentation of CNS tumor in VHL disease.

According to Knudson's two hit hypothesis, tumorigenesis in VHL disease is initiated by the "second hit", inactivation of the wild type copy of the VHL allele in patients that carry the VHL mutation (8). The recent identification of numerous VHL-deficient DASEs in tumor-free CNS tissues of VHL patients led to the conclusion that the "second hit" is necessary, but insufficient for tumorigenesis $(98,99)$. Instead, "second hits" appear to be capable of producing DASEs from which frank tumors may or may not develop. The nature of the third hit allowing DASEs to develop into frank tumor remains unknown.

\section{Persistence of temporary embryonal progenitor cells}

In VHL disease, the embryonal rest hypothesis does not necessarily imply the generation of neoplastic tissue during organ development. Instead, it implies the causative genetic hit to occur during organ development with the effect of developmental arrest of variable numbers of embryonal/fetal cells that have the capacity of eventual neoplastic proliferation. Key arguments are:

a) Organ selectivity: Precursor and tumor formation occurs abundantly in selective tissue structures, and not at all in others; In VHL disease, there is dramatically increased risk of development of hemangioblastoma, renal clear cell carcinoma, cystadenoma of pancreas and endolymphatic sac, and neuroendocrine tumors, but no increased risk for any other type of cancer. b) Tumor specificity: While large varieties of different tumors are known to exist in CNS and kidney, only tumors with specific histology occur in affected organs.

c) Consistent topographic distribution of precursor structures/tumors: Tissue development is strongly associated with pattern formation. VHL disease not only targets the nervous system, it does so in a near-predictable pattern of distribution. Neoplastic structures are frequently observed in spinal cord and cerebellum, only rarely in cerebrum. Within the cerebellum, the molecular layer is primarily affected. In spinal cord tissue, precursors/tumors are detected far more frequently in dorsal than in ventral roots. The most frequently affected specific topographic CNS site is the obex of the brainstem (E. Oldfield, personal communication).

d) Stem/progenitor cell properties of VHL deficient neoplastic cells: Multiple different analytic and/or experimental approaches have identified the VHL-deficient neoplastic cell as primitive hemangioblastic progenitor cell with capacity of differentiation into red blood cells and/or primitive vascular structures. Although not definitively demonstrated, there is strong supportive evidence for hemangioblastic differentiation to occur during brain (and even stronger evidence for kidney) development. Hemangioblastic cells are not part of the mature nervous system; instead, hemangioblastic cells persist in the nervous system due to pathologic events during tissue development and represent a condicio sine qua non for tumor development.

\section{Alternative hypotheses}

Alternative hypotheses for tumor development include a) tumorigenesis from a pre-existent glial, neuronal, or mesenchymal cell (100); b) tumorigenesis from circulating cells (101); c) tumorigenesis from a stem cell $(96,102$, 103).

a) Tumorigenesis from a pre-existent cell in the nervous system would imply dedifferentiation of mature cells into hemangioblastic progenitor cells which not 
only has never been demonstrated, but should be expected to be an extraordinarily complex molecular and structural process. Activation of HIF occurs in tissues under hypoxic stress, but is not known to be related to tumorigenesis. Structural analysis of precursor/tumor structures in the nervous system reveal the pathology to evolve from minute poorly differentiated foci into larger lesions with increased maturation (24), with erythropoiesis occurring only in largest-sized frank tumors (25). Simply, the abundance of minute structural changes in VHL tissues is explained more easily by an origin from VHL-deficient aberrant cells; furthermore, the most frequent occurrence of precursor structures in nerve root tissue provides a very limited set of candidate cells for tumor development.

b) Circulating bone marrow cells have been implicated in the generation of or contribution to brain tumors (101). This hypothesis would explain tumor specificity, but require bone marrow hematopoietic cells to be primarily targeted by the second hit. The VHL deficient hemangioblastic progenitor/stem cell is the most primitive form of hemangioblast, originally discovered in the yolk sac (45). To support this hypothesis, it would be necessary to demonstrate presence of these primitive hemangioblastic precursor cells in fetal or adult bone marrow. More difficult to explain, however, would be the principles of organ selectivity and topographic distribution of VHL tumors. In addition, bone marrow pathology is not known to exist in VHL disease.

c) Since VHL deficient tumor cells in nervous system have been identified as hemangioblastic progenitor cells, an origin from VHL-deficient stem cells with hemangioblastic differentiation potential certainly deserves consideration. While the role of stem cells in the brain remains controversial, a stem cell origin of brain (and many other) tumors is being increasingly accepted (103). By definition, stem cells are totipotent cells with differentiation potential along multiple (in the brain along astrocytic, oligodendroglial and neuronal) cell lineages which is not the case in VHL disease (tumor specificity). Nevertheless, while the pathogenic cell in
VHL nervous system remains bestcharacterized as VHL-deficient hemangioblastic progenitor cell, the second hit could occur in a totipotent stem cell, with VHL inactivation being exclusively permissive for hemangioblastic differentiation. However, the stem cell hypothesis fails to explain organ selectivity and consistent topographical lesion distribution within organs. Also, experimental knock-out of the VHL gene in cell systems has so far not revealed evidence for hemangioblastic differentiation.

In essence, stem cell hypothesis and embryonal rest hypothesis are not entirely exclusive. Like hematopoietic progenitor cells, stem cells are derived from embryonal cells. The key difference is the time of the second hit, VHL inactivation. The stem cell theory would allow for the second hit to occur any time, while the embryonic rest hypothesis postulates the second hit to occur early during tissue development, producing an early and pathologic set of VHL deficient hemangioblastic progenitor cells. It is the embryonic rest hypothesis which most comfortably explains the key arguments presented above.

This modified embryonal rest hypothesis has not been proven, but it most effortlessly explains clinical, pathologic and experimental evidence available so far. Similarly effortlessly it can be applied to any other classic tumor suppressor gene syndrome (e.g. MEN1, neurofibromatosis), with confirmatory literature on record. Thus, VHL disease is a naturally occurring human tumor suppressor gene "model" the unique features of which give insight into the biology of neoplastic disease and cancer.

\section{Conclusion}

VHL disease is a classic tumor suppressor gene syndrome caused by VHL gene germline mutation. In the nervous system, the "second hit" - VHL wild-type gene inactivation - induces DASEs which have the potential to develop into benign hemangioblastic tumors. In the kidney, VHL-deficient cells give rise to renal clear cell carcinoma which can metastasize into brain and spinal cord. Endolymphatic sac 
tumors may develop in the vestibular aqueduct with the potential of brain invasion. While the molecular consequences of VHL inactivation have been worked out in detail, fundamental questions have remained unexplained by these studies. The fundamental questions include organ selectivity, tumor specificity, the consistent lesional distribution pattern, and the embryonal/stem cell nature of the tumor cells. These intriguing features are best explained by the "second hit" occurring during nervous system development. Application of this concept may generate new research approaches to VHL-deficient tumors, their sporadic counterparts as well as tumors in the context of other tumor suppressor gene syndromes.

\section{Acknowledgements}

Many thanks to Dr. Douglas Brash for numerous fruitful scientific discussions.

\section{References}

1. Kaelin WG Jr. Molecular basis of the VHL hereditary cancer syndrome. Nat Rev Cancer. 2002;2(9):673-82.

http://dx.doi.org/10.1038/nrc885

2. Latif $\mathrm{F}$ et al. Identification of the von HippelLindau disease tumor suppressor gene. Science. 1993;260(5112):1317-20.

http://dx.doi.org/10.1126/science.8493574

3. Lonser RR, Glenn GM, Walther M, Chew EY, Libutti SK, Linehan WM, Oldfield EH. von Hippel-Lindau disease. Lancet. 2003;361(9374):2059-67.

http://dx.doi.org/10.1016/S01406736(03)13643-4

4. Haase VH. The VHL tumor suppressor in development and disease: functional studies in mice by conditional gene targeting. Semin Cell Dev Biol. 2005;16(4-5):564-74.

http://dx.doi.org/10.1016/j.semcdb.2005.03.0 06

5. Gnarra JR, Ward JM, Porter FD, Wagner JR, Devor DE, Grinberg A, Emmert-Buck MR, Westphal H, Klausner RD, Linehan WM. Defective placental vasculogenesis causes embryonic lethality in VHL-deficient mice. Proc Natl Acad Sci U S A. 1997;94(17):9102-7. http://dx.doi.org/10.1073/pnas.94.17.9102
6. Mack FA, Rathmell WK, Arsham AM, Gnarra $\mathrm{J}$, Keith B, Simon MC. Loss of pVHL is sufficient to cause HIF dysregulation in primary cells but does not promote tumor growth. Cancer Cell. 2003;3(1):75-88.

http:/ /dx.doi.org/10.1016/S1535-

6108(02)00240-4

7. Nyhan MJ, O'Sullivan GC, McKenna SL. Role of the VHL (von Hippel-Lindau) gene in renal cancer: a multifunctional tumour suppressor. Biochem Soc Trans. 2008;36(Pt 3):472-8. http://dx.doi.org/ 10.1042/BST0360472

8. Knudson AG. Hereditary cancer: two hits revisited. J Cancer Res Clin Oncol. 1996;122(3):135-40.

http:/ /dx.doi.org/10.1007/BF01366952

9. Iliopoulos O, Levy AP, Jiang C, Kaelin WG Jr, Goldberg MA. Negative regulation of hypoxiainducible genes by the von Hippel-Lindau protein. Proc Natl Acad Sci U S A. 1996;93(20):10595-9.

http://dx.doi.org/10.1073/pnas.93.20.10595

10. Krieg $M$, Haas $R$, Brauch $H$, Acker $T$, Flamme I, Plate KH. Up-regulation of hypoxiainducible factors HIF-1alpha and HIF-2alpha under normoxic conditions in renal carcinoma cells by von Hippel-Lindau tumor suppressor gene loss of function. Oncogene. 2000;19(48):5435-43.

http://dx.doi.org/10.1038/sj.onc. 1203938

11. Maxwell PH, Wiesener MS, Chang GW, Clifford SC, Vaux EC, Cockman ME, Wykoff CC, Pugh CW, Maher ER, Ratcliffe PJ. The tumour suppressor protein VHL targets hypoxiainducible factors for oxygen-dependent proteolysis. Nature. 1999;399(6733):271-5. http://dx.doi.org/10.1038/20459

12. Semenza GL. Targeting HIF-1 for cancer therapy. Nat Rev Cancer. 2003;3(10):721-32. http:/ /dx.doi.org/10.1038/nrc1 187

13. Tian H, McKnight SL, Russell DW. Endothelial PAS domain protein 1 (EPAS1), a transcription factor selectively expressed in endothelial cells. Genes Dev. 1997;11(1):72-82. http://dx.doi.org/10.1101/gad.11.1.72

14. Simon MC, Keith B. The role of oxygen availability in embryonic development and stem cell function. Nat Rev Mol Cell Biol. 2008;9(4):285-96.

http://dx.doi.org/10.1038/nrm2354

15. Lisztwan $\mathrm{J}$, Imbert $\mathrm{G}$, Wirbelauer $\mathrm{C}$, Gstaiger M, Krek W. The von Hippel-Lindau tumor suppressor protein is a component of an 
E3 ubiquitin-protein ligase activity. Genes Dev. 1999;13(14): 1822-33.

http://dx.doi.org/10.1101/gad.13.14.1822

16. Lonergan KM, Iliopoulos $\mathrm{O}$, Ohh M, Kamura $\mathrm{T}$, Conaway RC, Conaway JW, Kaelin WG Jr. Regulation of hypoxia-inducible mRNAs by the von Hippel-Lindau tumor suppressor protein requires binding to complexes containing elongins $\mathrm{B} / \mathrm{C}$ and Cul2. Mol Cell Biol. 1998;18(2):732-41.

17. Pause A, Lee S, Worrell RA, Chen DY, Burgess WH, Linehan WM, Klausner RD. The von Hippel-Lindau tumor-suppressor gene product forms a stable complex with human CUL-2, a member of the Cdc53 family of proteins. Proc Natl Acad Sci U S A. 1997;94(6):2156-61.

http:/ / dx.doi.org/10.1073/pnas.94.6.2156

18. Cockman ME, Masson N, Mole DR, Jaakkola P, Chang GW, Clifford SC, Maher ER, Pugh CW, Ratcliffe PJ, Maxwell PH. Hypoxia inducible factor-alpha binding and ubiquitylation by the von Hippel-Lindau tumor suppressor protein. J Biol Chem. 2000;275(33):25733-41.

http://dx.doi.org/10.1074/jbc.M002740200

19. Ohh M, Park CW, Ivan M, Hoffman MA, Kim TY, Huang LE, Pavletich N, Chau V, Kaelin WG. Ubiquitination of hypoxia-inducible factor requires direct binding to the beta-domain of the von Hippel-Lindau protein. Nat Cell Biol. 2000;2(7):423-7.

http://dx.doi.org/10.1038/35017054

20. Jiang BH, Zheng JZ, Leung SW, Roe R, Semenza GL. Transactivation and inhibitory domains of hypoxia-inducible factor 1 alpha. Modulation of transcriptional activity by oxygen tension. J Biol Chem. 1997;272(31):19253-60. http:/ /dx.doi.org/ 10.1074/jbc.272.31.19253

21. Ema M, Taya S, Yokotani N, Sogawa K, Matsuda Y, Fujii-Kuriyama Y. A novel bHLHPAS factor with close sequence similarity to hypoxia-inducible factor 1alpha regulates the VEGF expression and is potentially involved in lung and vascular development. Proc Natl Acad Sci U S A. 1997;94(9):4273-8.

http:/ /dx.doi.org/10.1073/pnas.94.9.4273

22. Rankin EB, Biju MP, Liu Q, Unger TL, Rha J, Johnson RS, Simon MC, Keith B, Haase VH. Hypoxia-inducible factor-2 (HIF-2) regulates hepatic erythropoietin in vivo. $\mathrm{J}$ Clin Invest. 2007;117(4):1068-77.

http://dx.doi.org/10.1172/JCI30117

23. Gruber $\mathrm{M}, \mathrm{Hu} \mathrm{CJ}$, Johnson RS, Brown EJ, Keith B, Simon MC. Acute postnatal ablation of
Hif-2alpha results in anemia. Proc Natl Acad Sci U S A. 2007;104(7):2301-6.

http:/ /dx.doi.org/10.1073/pnas.0608382104

24. Vortmeyer AO et al. Evolution of VHL tumourigenesis in nerve root tissue. $J$ Pathol. 2006 Nov;210(3):374-82.

http://dx.doi.org/10.1002/path.2062

25. Shively SB, Beltaifa S, Gehrs B, Duong H, Smith J, Edwards NA, Lonser R, Raffeld M, Vortmeyer AO. Protracted haemangioblastic proliferation and differentiation in von HippelLindau disease. J Pathol. 2008;216(4):514-20. http://dx.doi.org/10.1002/path.2435

26. Lindau A. Studien über Kleinhirncysten. Bau, Pathogenese und Beziehungen zur Angiomatosis retinae. Copenhagen; 1926.

27. Lindau A. Discussion on vascular tumors of the brain and spinal cord. Proc R Soc Med. 1931; 24: 363 .

28. Vortmeyer AO, Falke EA, Glasker S, Li J, Oldfield EH. Nervous system involvement in von Hippel-Lindau disease: pathology and mechanisms. Acta Neuropathol. 2013;125(3):333-50.

http:/ / dx.doi.org/ 10.1007/s00401-013-1091-Z

29. Maher ER, Yates JR, Harries R, Benjamin C, Harris R, Moore AT, Ferguson-Smith MA. Clinical features and natural history of von Hippel-Lindau disease. Q J Med. 1990;77(283):1151-63.

http://dx.doi.org/10.1093/qjmed/77.2.1151

30. Wanebo JE, Lonser RR, Glenn GM, Oldfield $\mathrm{EH}$. The natural history of hemangioblastomas of the central nervous system in patients with von Hippel-Lindau disease. J Neurosurg. 2003;98(1):82-94.

http:/ / dx.doi.org/ 10.3171/jns.2003.98.1.0082

31. Grisoli F, Gambarelli D, Raybaud C, Guibout M, Leclercq T. Suprasellar hemangioblastoma. Surg Neurol. 1984;22(3):257-62.

http:/ /dx.doi.org/ 10.1016/00903019(84)90010-7

32. Neumann HP, Eggert HR, Weigel K, Friedburg H, Wiestler OD, Schollmeyer P. Hemangioblastomas of the central nervous system. A 10-year study with special reference to von Hippel-Lindau syndrome. J Neurosurg. 1989;70(1):24-30.

http://dx.doi.org/10.3171/jns.1989.70.1.0024

33. Lonser RR, Vortmeyer AO, Butman JA, Glasker S, Finn MA, Ammerman JM, Merrill MJ, 
Edwards NA, Zhuang Z, Oldfield EH. Edema is a precursor to central nervous system peritumoral cyst formation. Ann Neurol. 2005;58(3):392-9. http://dx.doi.org/ 10.1002/ana.20584

34. Resche F, Moisan JP, Mantoura J, de Kersaint-Gilly A, Andre MJ, Perrin-Resche I, Menegalli-Boggelli D, Lajat Y, Richard S. Haemangioblastoma, haemangioblastomatosis, and von Hippel-Lindau disease. Adv Tech Stand Neurosurg. 1993;20:197-304.

http:/ /dx.doi.org/ 10.1007/978-3-7091-6912466

35. Filling-Katz MR et al. Central nervous system involvement in Von Hippel-Lindau disease. Neurology. 1991;41(1):41-6.

http://dx.doi.org/10.1212/WNL.41.1.41

36. Vortmeyer AO, Gnarra JR, Emmert-Buck MR, Katz D, Linehan WM, Oldfield EH, Zhuang $Z$. von Hippel-Lindau gene deletion detected in the stromal cell component of a cerebellar hemangioblastoma associated with von HippelLindau disease. Hum Pathol. 1997;28(5):540-3. http:/ /dx.doi.org/10.1016/S00468177(97)90075-7

37. Lee JY et al. Loss of heterozygosity and somatic mutations of the VHL tumor suppressor gene in sporadic cerebellar hemangioblastomas. Cancer Res. 1998;58(3):504-8.

38. Plate K. H. VAO, Zagzag D., Neumann H.P.H. Familial Tumour Syndromes involving the Nervous System. In: Louis DN, ed. WHO classification of tumours of the central nervous system: World Health Organization (WHO), 2007.

39. Cushing $\mathrm{H}$ BP. Tumors Arising from the Blood-Vessels of the Brain. Angiomatous Malformations and Hemangioblastomas. In: Thomas CC, ed. Springfield, 1928.

40. Stein AA, Schilp AO, Whitfield RD. The histogenesis of hemangioblastoma of the brain. A review of twenty-one cases. J Neurosurg. 1960;17:751-61.

http://dx.doi.org/10.3171/jns.1960.17.4.0751

41. Gläsker S, Li J, Xia JB, Okamoto H, Zeng W, Lonser RR, Zhuang Z, Oldfield EH, Vortmeyer AO. Hemangioblastomas share protein expression with embryonal hemangioblast progenitor cell. Cancer Res. 2006;66(8):416772 .

http:/ /dx.doi.org/ 10.1158/0008-5472.CAN-053505

42. Vortmeyer AO et al. Developmental arrest of angioblastic lineage initiates tumorigenesis in von Hippel-Lindau disease. Cancer Res. 2003;63(21):7051-5.

43. Sabin FR. Preliminary note on the differentiation of angioblasts and the method by which they produce blood-vessels, blood-plasma and red blood-cells as seen in the living chick. 1917. J Hematother Stem Cell Res. 2002;11(1):5-7.

http://dx.doi.org/10.1089/1525816027534484 96

44. Sabin FR. Studies on the origin of the blood vessels and of red blood corpuscles as seen in the living blastoderm of chick during the second day of incubation. Carnegie Contrib Embryol. 1920; 9: 215

45. Sabin FR. Preliminary note on the differentiation of angioblasts and the method by which they produce blood-vessels, blood-plasma and red blood-cells as seen in the living chick. Anat Rec. 1917; 13: 199.

http://dx.doi.org/10.1002/ar.1090130403

46. Glasker S, Smith J, Raffeld M, Li J, Oldfield EH, Vortmeyer AO. VHL-deficient vasculogenesis in hemangioblastoma. Exp Mol Pathol. 2014;96(2):162-7. http://dx.doi.org/10.1016/j.yexmp.2013.12.01 1

47. Wizigmann-Voos S, Breier G, Risau W, Plate $\mathrm{KH}$. Up-regulation of vascular endothelial growth factor and its receptors in von HippelLindau disease-associated and sporadic hemangioblastomas. Cancer Res. 1995;55(6):1358-64.

48. Tanimura A, Nakamura $Y$, Hachisuka $H$, Tanimura Y, Fukumura A. Hemangioblastoma of the central nervous system: nature of the stromal cells as studied by the immunoperoxidase technique. Hum Pathol. 1984;15(9):866-9.

http:/ /dx.doi.org/10.1016/S0046-

8177(84)80148-3

49. Becker I, Paulus W, Roggendorf W. Histogenesis of stromal cells in cerebellar hemangioblastomas. An immunohistochemical study. Am J Pathol. 1989;134(2):271-5.

50. Frank TS, Trojanowski JQ, Roberts SA, Brooks JJ. A detailed immunohistochemical analysis of cerebellar hemangioblastoma: an undifferentiated mesenchymal tumor. Mod Pathol. 1989;2(6):638-51.

51. Nemes Z. Fibrohistiocytic differentiation in capillary hemangioblastoma. Hum Pathol. 1992;23(7):805-10. 
http:/ /dx.doi.org/10.1016/0046-

8177(92)90351-3

52. Kamitani H, Masuzawa H, Sato J, Kanazawa I. Capillary hemangioblastoma: histogenesis of stromal cells. Acta Neuropathol. 1987;73(4):370-8.

http:/ /dx.doi.org/ 10.1007 /BF00688262

53. Cruz-Sanchez FF, Rossi ML, RodriguezPrados S, Nakamura N, Hughes JT, Coakham HB. Haemangioblastoma: histological and immunohistological study of an enigmatic cerebellar tumour. Histol Histopathol. 1990;5(4):407-13.

54. Jurco S 3rd, Nadji M, Harvey DG, Parker JC Jr, Font RL, Morales AR. Hemangioblastomas: histogenesis of the stromal cell studied by immunocytochemistry. Hum Pathol. 1982;13(1):13-8.

http://dx.doi.org/10.1016/S0046-

8177(82)80133-0

55. Omulecka A, Lach B, Alwasiak J, Gregor A. Immunohistochemical and ultrastructural studies of stromal cells in hemangioblastoma. Folia Neuropathol. 1995;33(1):41-50.

56. Lach B, Gregor A, Rippstein P, Omulecka A. Angiogenic histogenesis of stromal cells in hemangioblastoma: ultrastructural and immunohistochemical study. Ultrastruct Pathol. 1999;23(5):299-310.

http:/ /dx.doi.org/10.1080/019131299281446

57. Spence AM, Rubinstein LJ. Cerebellar capillary hemangioblastoma: its histogenesis studied by organ culture and electron microscopy. Cancer. 1975;35(2):326-41. http: / /dx.doi.org/10.1002/1097-

0142(197502)35:2<326::AID-

CNCR2820350206>3.0.CO;2-8

58. Park DM et al. von Hippel-Lindau diseaseassociated hemangioblastomas are derived from embryologic multipotent cells. PLoS Med. 2007;4(2):e60.

http://dx.doi.org/10.1371/journal.pmed.00400 60

59. Zhuang Z, Frerich JM, Huntoon K, Yang C, Merrill MJ, Abdullaev Z, Pack SD, Shively SB, Stamp G, Lonser RR. Tumor derived vasculogenesis in von Hippel-Lindau diseaseassociated tumors. Sci Rep. 2014;4:4102. http://dx.doi.org/10.1038/srep04102

60. Hasselblatt M, Jeibmann A, Gerss J, Behrens C, Rama B, Wassmann H, Paulus W. Cellular and reticular variants of haemangioblastoma revisited: a clinicopathologic study of 88 cases. Neuropathol
Appl Neurobiol. 2005;31(6):618-22. http: / / dx.doi.org/10.1111/j.1365-

2990.2005.00669.x

61. Netter FH CS. Atlas of Human Anatomy. Summit: Ciba Geigy Corporation, 1989. PMCid:PMC1003780

62. Lo WW, Daniels DL, Chakeres DW, Linthicum FH Jr, Ulmer JL, Mark LP, Swartz JD. The endolymphatic duct and sac. AJNR Am J Neuroradiol. 1997;18(5):881-7.

63. Arenberg IK, Rask-Andersen H, Wilbrand H, Stahle J. The surgical anatomy of the endolymphatic sac. Arch Otolaryngol. 1977;103(1):1-11.

http:/ / dx.doi.org/ 10.1001/archotol.1977.0078 0180039001

64. Gläsker S, Lonser RR, Tran MG, Ikejiri B, Butman JA, Zeng W, Maxwell PH, Zhuang Z, Oldfield EH, Vortmeyer AO. Effects of VHL deficiency on endolymphatic duct and sac. Cancer Res. 2005;65(23):10847-53.

http: / /dx.doi.org/ 10.1158/0008-5472.CAN-051104

65. Wackym PA1, Glasscock ME 3rd, Linthicum FH Jr, Friberg U, Rask-Andersen $\mathrm{H}$. Immunohistochemical localization of $\mathrm{Na}+\mathrm{K}+-$ ATPase in the human endolymphatic sac. Arch Otorhinolaryngol. 1988;245(4):221-3.

http://dx.doi.org/10.1007/BF00463931

66. Morgenstern C, Amano H, Orsulakova A. Ion transport in the endolymphatic space. Am J Otolaryngol. 1982;3(5):323-7.

http://dx.doi.org/10.1016/S0196-

0709(82)80004-5

67. Erwall C, Friberg U, Bagger-Sjoback D, Rask-Andersen H. Degradation of the homogeneous substance in the endolymphatic sac. Acta Otolaryngol. 1988;105(3-4):209-17. http://dx.doi.org/ 10.3109/0001648880909700 0

68. Harris JP. Autoimmunity of the inner ear. Am J Otol. 1989;10(3):193-5.

69. Heffner DK. Low-grade adenocarcinoma of probable endolymphatic sac origin A clinicopathologic study of 20 cases. Cancer. 1989;64(11):2292-302.

http:/ /dx.doi.org/10.1002/1097-

0142(19891201)64:11<2292::AID-

CNCR2820641119>3.0.CO;2-\#

70. Manski TJ et al. Endolymphatic sac tumors. A source of morbid hearing loss in von HippelLindau disease. JAMA. 1997;277(18):1461-6. 
http://dx.doi.org/10.1001/jama.1997.0354042 0057030

71. Kawahara N, Kume H, Ueki K, Mishima K, Sasaki T, Kirino T. VHL gene inactivation in an endolymphatic sac tumor associated with von Hippel-Lindau disease. Neurology. 1999;53(1):208-10.

http://dx.doi.org/10.1212/WNL.53.1.208

72. Vortmeyer AO, Choo D, Pack SD, Oldfield E, Zhuang $Z$. von Hippel-Lindau disease gene alterations associated with endolymphatic sac tumor. J Natl Cancer Inst. 1997;89(13):970-2. http://dx.doi.org/10.1093/jnci/89.13.970-a

73. Vogel TW, Vortmeyer AO, Lubensky IA, Lee YS, Furuta M, Ikejiri B, Kim HJ, Lonser RR, Oldfield EH, Zhuang $Z$. Coexpression of erythropoietin and its receptor in endolymphatic sac tumors. J Neurosurg. 2005;103(2):284-8. http://dx.doi.org/10.3171/jns.2005.103.2.028 4

74. Megerian CA, Haynes DS, Poe DS, Choo DI, Keriakas TJ, Glasscock ME 3rd. Hearing preservation surgery for small endolymphatic sac tumors in patients with von Hippel-Lindau syndrome. Otol Neurotol. 2002;23(3):378-87. http:/ /dx.doi.org/10.1097/00129492200205000-00026

75. Thompson LD. Endolymphatic sac tumor. Ear Nose Throat J. 2013;92(4-5):184-8.

76. Butman JA, Kim HJ, Baggenstos M, Ammerman JM, Dambrosia J, Patsalides A, Patronas NJ, Oldfield EH, Lonser RR. Mechanisms of morbid hearing loss associated with tumors of the endolymphatic sac in von Hippel-Lindau disease. JAMA. 2007;298(1):418.

http://dx.doi.org/10.1001/jama.298.1.41

77. Lonser RR, Kim HJ, Butman JA, Vortmeyer AO, Choo DI, Oldfield EH. Tumors of the endolymphatic sac in von Hippel-Lindau disease. N Engl J Med. 2004;350(24):2481-6. http:/ /dx.doi.org/ 10.1056/NEJMoa040666

78. Du J, Wang JM, Cui Y, Li GL. [Clinicopathologic features of endolymphatic sac tumor at cerebellopontine angle]. Zhonghua Bing Li Xue Za Zhi. 2011;40(9):590-4 (Chinese journal of pathology. 2011; 40(9): 590-4).

79. Kempermann G, Neumann HP, Volk B. Endolymphatic sac tumours. Histopathology. 1998;33(1):2-10.

http://dx.doi.org/10.1046/j.1365-

2559.1998.00460.x
80. Michaels L. Origin of endolymphatic sac tumor. Head Neck Pathol. 2007;1(2):104-11. http:/ /dx.doi.org/10.1007/s12105-007-0016-3

81. Andrew SM, Gradwell E. Immunoperoxidase labelled antibody staining in differential diagnosis of central nervous system haemangioblastomas and central nervous system metastases of renal carcinomas. J Clin Pathol. 1986;39(8):917-9.

http:/ /dx.doi.org/10.1136/jcp.39.8.917

82. Gouldesbrough DR, Bell JE, Gordon A. Use of immunohistochemical methods in the differential diagnosis between primary cerebellar haemangioblastoma and metastatic renal carcinoma. J Clin Pathol. 1988;41(8):861-5. http://dx.doi.org/10.1136/jcp.41.8.861

83. Vortmeyer AO, Weil RJ, Zhuang $Z$. Proteomic applications for differential diagnosis of histologically identical tumors. Neurology. 2003;61(11):1626-7.

http://dx.doi.org/10.1212/01.WNL.000009616 8.85260 .60

84. Hoang MP, Amirkhan RH. Inhibin alpha distinguishes hemangioblastoma from clear cell renal cell carcinoma. Am J Surg Pathol. 2003;27(8):1152-6.

http:/ / dx.doi.org/10.1097/00000478-

200308000-00014

85. Ingold B, Wild PJ, Nocito A, Amin MB, Storz M, Heppner FL, Moch H. Renal cell carcinoma marker reliably discriminates central nervous system haemangioblastoma from brain metastases of renal cell carcinoma. Histopathology. 2008;52(6):674-81.

http:/ /dx.doi.org/10.1111/j.1365-

2559.2008.03003.x

86. Jung SM, Kuo TT. Immunoreactivity of CD10 and inhibin alpha in differentiating hemangioblastoma of central nervous system from metastatic clear cell renal cell carcinoma. Mod Pathol. 2005;18(6):788-94.

http://dx.doi.org/10.1038/modpathol.3800351

87. Roy S, Chu A, Trojanowski JQ, Zhang PJ. D2-40, a novel monoclonal antibody against the M2A antigen as a marker to distinguish hemangioblastomas from renal cell carcinomas. Acta Neuropathol. 2005;109(5):497-502.

http: / /dx.doi.org/ 10.1007/s00401-005-0999-3

88. Weinbreck N, Marie B, Bressenot A, Montagne K, Joud A, Baumann C, Klein O, Vignaud JM. Immunohistochemical markers to distinguish between hemangioblastoma and metastatic clear-cell renal cell carcinoma in the brain: utility of aquaporin 1 combined with 
cytokeratin AE1/AE3 immunostaining. Am J Surg Pathol. 2008;32(7):1051-9.

http:/ /dx.doi.org/ 10.1097/PAS.Ob013e318160 $9 \mathrm{~d} 7 \mathrm{~d}$

89. Carney EM, Banerjee P, Ellis CL, Albadine R, Sharma R, Chaux AM, Burger PC, Netto GJ. PAX2(-)/PAX8(-)/inhibin $\mathrm{A}(+)$ immunoprofile in hemangioblastoma: A helpful combination in the differential diagnosis with metastatic clear cell renal cell carcinoma to the central nervous system. Am J Surg Pathol. 2011;35(2):262-7. http://dx.doi.org/10.1097/PAS.0b013e318206 4d 11

90. Jarrell ST, Vortmeyer AO, Linehan WM, Oldfield EH, Lonser RR. Metastases to hemangioblastomas in von Hippel-Lindau disease. J Neurosurg. 2006;105(2):256-63.

http://dx.doi.org/10.3171/jns.2006.105.2.256

91. Mottolese C, Stan H, Giordano F, Frappaz D, Alexei D, Streichenberger N. Metastasis of clearcell renal carcinoma to cerebellar hemangioblastoma in von Hippel Lindau disease: rare or not investigated? Acta Neurochir (Wien). 2001;143(10):1059-63. http://dx.doi.org/10.1007/s007010170012

92. Sell S. Stem Cells and Cancer. New York: Springer, 2009.

93. Grundmann E. [The concept of Julius Cohnheim on tumor formation and metastasis from the viewpoint of new research results]. Zentralbl Allg Pathol. 1985;130(4):323-31.

94. Durante F. Nesso fisio-pathologico tra la struttura dei nei materni e la genesi di alcuni tumori maligni. Arch Memor Osser Chir Pract $1874 ; 11: 217-226$

95. Bainbridge W. The cancer problem. New York: The Macmillan Company, 1918.
96. Sell S. On the stem cell origin of cancer. Am J Pathol. 2010;176(6):2584-494.

http://dx.doi.org/ 10.2353/ajpath.2010.091064

97. Shively SB, Falke EA, Li J, Tran MG, Thompson ER, Maxwell PH, Roessler E, Oldfield EH, Lonser RR, Vortmeyer AO.. Developmentally arrested structures preceding cerebellar tumors in von Hippel-Lindau disease. Mod Pathol. 2011;24(8):1023-30.

http:/ / dx.doi.org/ 10.1038/modpathol.2011.61

98. Vortmeyer AO, Yuan Q, Lee YS, Zhuang Z, Oldfield EH. Developmental effects of von Hippel-Lindau gene deficiency. Ann Neurol. 2004;55(5):721-8.

http://dx.doi.org/10.1002/ana.20090

99. Gläsker S, Sohn TS, Okamoto H, Li J, Lonser RR, Oldfield EH, Vortmeyer AO, Zhuang $Z$. Second hit deletion size in von Hippel-Lindau disease. Ann Neurol. 2006;59(1):105-10. http:/ /dx.doi.org/ 10.1002/ana.20704

100. Visvader JE. Cells of origin in cancer. Nature. 2011;469(7330):314-22. http://dx.doi.org/10.1038/nature09781

101.Liu C, Chen Z, Chen Z, Zhang T, Lu Y. Multiple tumor types may originate from bone marrow-derived cells. Neoplasia. 2006;8(9):71624.

http:/ /dx.doi.org/ 10.1593/neo.06253

102. Ratajczak MZ, Sellers ZP, Kucia M, Kakar SS. The embryonic rest hypothesis of cancer development - and old XIX century theory revisited. J Cancer Stem Cell Res 01/2014; $1(1): 1$.

http://dx.doi.org/10.14343/JCSCR.2014.1e10 01

103. White AC, Lowry WE. Refining the role for adult stem cells as cancer cells of origin. Trends Cell Biol. 2015;25(1):11-20.

http://dx.doi.org/10.1016/j.tcb.2014.08.008 